\title{
CONRAD'S ARTISTIC RETURNS: PERSPECTIVES ON A BULGARIAN DEBUT IN STAGING HEART OF DARKNESS ${ }^{1}$
}

\author{
Margreta Grigorova \\ (iD) http:/orcid.org/0000-0003-4416-371X \\ Petya Tsoneva \\ iD http:/orcid.org/0000-0002-8973-6406
}

(St. Cyril and St. Methodius University of Veliko Tarnovo, Bulgaria)

\begin{abstract}
Since 1989 (the fall of Communism) the performing arts in Bulgaria have suffered a long process of transition dominated by a certain dialectic tension between the necessity to meet economic needs and the desire to open new venues for dramatic art. Against this background and contributing its own perceptive "reading" of Heart of Darkness to Conrad's Bulgarian reception, on the eve of the vigorous celebration of his 160th anniversary in 2017, stage director Valeria Valcheva's theatrical adaptation represents a remarkable debut rendition of Conrad's fiction. The aim of this article is to explore how her idiosyncratic, creative, poetically recognizable approach lends a new form to Conrad's recurrent relocation in modern and contemporary Bulgarian art.
\end{abstract}

Keywords: Joseph Conrad, Heart of Darkness, Valeria Valcheva, performing arts, theatrical reception, theatrical translation, experimental theatre

Yet why Heart of Darkness here and now? Is it because of the colonial crises then or the migrant crises of today?

Joseph Conrad questions the existential foundations of human nature. We need to flesh them out in an appropriate way, even though Conrad was convinced that the human quest for answers has always been haunted by an anxious anticipation of the answers.

Valeria Valcheva, Heart of Darkness (play announcement)

\footnotetext{
${ }^{1}$ The present article complements, expands and rethinks the authors' latest study of the Bulgarian dramatization of Heart of Darkness, published in Bulgarian in Proglas journal, aiming to contribute to the discussions of Conrad's reception in a wider academic space. See Margreta Grigorova and Petya Tsoneva, " 'Sartseto na mraka' - idei i resheniya na parvata balgarska postanovka" [Heart of Darkness on the Bulgarian Stage: Creative Perspectives and Techniques], Proglas 28, no. 1 (2019), pp. 35-46.
} 


\section{CONRAD RETURNS... ON STAGE}

The turn of the new millennium, or, more precisely, from 2007 onwards (the year of Joseph Conrad's 150th anniversary), ${ }^{2}$ can certainly be located as the time when Conrad enters Bulgarian cultural space once again, but in an outstanding and unprecedented fashion. This return occurs both as one of the many occasions of the writer's re-emergence through creative and critical reassessments of his life and work in Bulgaria, and as a one-time innovative appearance that marks a substantial stage of Conrad's Bulgarian reception. Coincidentally, the period likewise overlaps with Bulgaria's accession to the EU, which, in turn, exerts its effect on the periodization of Bulgarian cultural development and, in particular, on the role of the Bulgarian theatre. Since 1989 (the fall of Communism) the performing arts in Bulgaria have undergone a long process of transition, which, as Kamelia Nikolova puts it, was dominated by an "intensive negotiation between the quest for freedom and renovation, and the quest for survival." ${ }^{3}$ The early twenty-first century was traumatically encumbered by terrorist attacks and the haunting anxiety of "untrodden paths of freedom," " while Nikolova refers to the period after 2007 as the time when "theatre ends the artistic indulgence of borrowed forms," $"$ when innovative poetic devices were more and more eagerly developed.

Within this context, and contributing its own perceptive "reading" of Heart of Darkness to Conrad's Bulgarian reception, on the eve of the vigorous celebration of his 160th anniversary in 2017, Valeria Valcheva's theatrical adaptation represents a remarkable debut rendition of Conrad's fiction. Her idiosyncratic, creative, poetically recognizable approach lends a new form to Conrad's recurrent relocation in modern and contemporary Bulgarian art; and this creative endeavour becomes even more recognizable as it focuses on one of his emblematic writings. Seen by Frederick R. Karl as "possibly the greatest short novel in English, one of the greatest in any language," $"$ subject to multiple discursive paradigms and interpretations, Heart of Darkness is a work whose repercussions have spread far and wide across the world. Its phenomenal impact reverberates in the proliferation of the creative responses it evokes, some of which are nonetheless conditioned by the spatiotemporal phenome-

\footnotetext{
${ }^{2}$ In 2007 the Embassy of Poland and the Polish Cultural Institute in Sofia took the initiative to honour and popularize Conrad's 150th anniversary organising a variety of events in both the capital and the bigger cities: a thematic biographical exhibition titled "Between the Dry Land and the Sea" took place at the Library of Sofia and the Festival and Congress Centre of the coastal city of Varna, other commemorations and academic lectures followed suit. Though the press launched only brief comments, this was the time that set the beginning of the first profound and comprehensive researches on Conrad.

${ }^{3}$ Kamelia Nikolova, Balgarskiyat teatar sled 1989 i novata britanska drama (Sofia: Sofia University Press, 2013), p. 247.

${ }^{4}$ Nikolova, Balgarskiyat teatar, p. 256.

${ }^{5}$ Nikolova, Balgarskiyat teatar, p. 258.

${ }^{6}$ Frederick R. Karl, AReader's Guideto Joseph Conrad (Syracuse: Syracuse University Press, 1960), p. 135.
} 
nology of its initial formulation. ${ }^{7}$ As Peter Firchow observes, "today it is still read and remembered, whereas Casement's and Morel's works are forgotten." ${ }^{8}$ The contemporary Bulgarian artistic platform which will be the subject of this article's discussion, reasserts the assumption that though being overly exploited in critical debates, Conrad's masterpiece continues to expand through periodical "returns" and that the theatrical adaptation in question is one of its recent creative interpretations. "I am convinced that Conrad's work 'flows' with the flow of time and the longer we spend time with him, the deeper we see," Valcheva confesses in a conversation. "Conrad was right in many of his views. His writing is amazingly compatible with today's world. The text is "contemporary," she adds. ${ }^{\text {" }}$

Conrad's present return celebrates an awareness deeper than the one it used to previously enjoy; it is further articulated within the context of the streamlined search, inspection and deliberation on Conrad's reception, initiated to a large extent by the authors of this work, who form a team specifically suited for this research by being made up of scholars of Polish and English studies (academic teachers at the University of Veliko Tarnovo), and who collaborate with other Bulgarian researchers and

${ }^{7}$ The breadth of the critical and creative responses to Conrad's work can be attributed to at least two major aspects of the text. The first one concerns the flexible articulation of the topos of "heart of darkness," which Conrad launches in a cultural "turnover" of endless circulation, where the given topos is constantly transferred across time and space and relocated to different situations, critical reasonings, literary and other cultural rewritings. Such, for instance, is Werner Herzog's cinematic adaptation Aguirre, the Wrath of God (1972) and Francis Ford Coppola's Apocalypse Now (1974). The novel's spectacular resonance also articulates the specific political conditions of Belgian Congo which found itself at the heart of international protests against King Leopold II's colonial rule. Actually, quite a few of Conrad's contemporaries produced works that argued against his authoritarian regime-Roger Casement (Correspondence and Report from His Majesty's Consul at Boma respecting the Administration of the Independent State of the Congo, 1904), Edmund D. Morel (King Leopold's Rule in Africa, 1904; The Black Ma's Burden, 1920), Arthur Conan Doyle (The Crime of the Congo, 1909). The Democratic Republic of Congo (what used to be Belgian Congo) continues to be reimagined as the "heart of darkness" in, for instance, Alberto Moravia, A quale tribù appartieni? (1972); Ernesto Guevara, Pasajes de la guerra revolucionaria: Congo (1997); Ryszard Kapuściński, Chrystus z karabinem na ramieniu (1975); Claus Hugo, De geruchten (1996); Mario Vargas Llosa, El sueño del celta (2010). The problem of the novel's reception along multiple discursive lanes and its prolific rewrites is likewise discussed in two chapters of M. Grigorova's monograph Joseph Conrad Korzeniowski-The Creator as Seafarer: "Sea, Migration and Biography in Conrad's Works" and "Locating Heart of Darkness. A Journey to the Centre of Africa. The Belgian Congo in Conrad's Works" (Veliko Tarnovo: St. Cyril and St. Methodius University Press, 2011). The fictional modifications of the Congo River are the subject of Petya Tsoneva's article "The Sea as Moving Threshold. Spaces of Transition in Joseph Conrad," ed. Irma Ratiani, National Literatures and the Process of Cultural Globalization, vol. 2 (Tbilisi: Shota Rustaveli Institute of Georgian Literature, 2014), pp. 137-146, and her comparative study "Waterways and Air Lanes: Spaces of Transition in Joseph Conrad, Antoine de Saint-Exupéry and Salman Rushdie," Yearbook of Conrad Studies (Poland), vol. 10 (2015), pp. 95-102.

${ }^{8}$ Peter E. Firchow, Envisioning Africa: Racism and Imperialism in Conrad's Heart of Darkness (Lexington, KY: University Press of Kentucky, 2015), p. x.

${ }^{9}$ Conversations with the film director were held prior to writing this article. Parts of them are included in a published interview with Valeria Valcheva conducted by Margreta Grigorova. For further reference, see " 'Come and See for Yourself!' Valeria Valcheva, Director of the First Bulgarian Cinematic Adaptation of Heart of Darkness," Proglas 28, no. 1 (2019), pp. 137-142. 
artists. ${ }^{10}$ Our conversation with stage director Valeria Valcheva also testifies in a convincing way to the collective experience of Conrad's work triggered by her production. In fact, the performance bound the most enthusiastic spectators, intellectuals and scholars to a very particular spontaneously formed society of Conrad's followers. Initially, we attempted to locate the "Pole of the world" ${ }^{11}$ within the Bulgarian context and then we did some work to present his Bulgarian reception within a larger international context, prompted mostly by foreign organisers of events honouring Conrad. ${ }^{12}$ Quite a lot has been done in this respect over the past ten years, which cover the period between two round anniversaries of Conrad's birth.

So far our study of Conrad's Bulgarian reception has been focused mainly on the reception through translation and reviews, from where we started our further critical observations of the Bulgarian maritime literature prior to and after the Second World War. That particular period saw the first publications in foreign editions of the critical comments and analyses that contributed to Conrad's Bulgarian reception, ${ }^{13}$ supplemented by other research articles related to his works and published in Bulgarian and foreign editions. ${ }^{14}$

${ }^{10}$ Our "thank you" goes to Assoc. Prof. Asparuh Asparuhov (author of the unpublished dissertation Symbol and Scene in Joseph Conrad's Early and Late Works, 1996) and Stefana Roussenova, author of Dialogues in Exile: Joseph Conrad, Vladimir Nabokov, Eva Hoffman (Sofia: Polis, 2010). We are likewise particularly indebted to Ludmilla Kostova, Professor of English and Irish Studies at the University of Veliko Tarnovo, for her expert advice and evaluation of our work. Our further investigation of Conrad's reception was greatly assisted by contacts with contemporary writers and writing sailors who confessed to have turned to Conrad both in their choice of profession and in their writing. These are the 102-year-old captain Vassil Valchanov (1915-2017), author of memoirs, and maritime writer Georgi Ingilizov (19552018). Our interviews with them have recently been published.

${ }^{11}$ The expression is borrowed from Margreta Grigorova's article "Joseph Conrad Korzeniowski- the Pole of the World." Thematic issue of the Literature Gazette (2017/18), pp. 19, 40, edited by M. Grigorova. The issue, published at the initiative of the Polish Institute in Sofia, contains articles and academic works by over sixteen scholars from Poland, the UK, the US, Slovakia, France, and Iran.

${ }^{12}$ The direction of our research was substantially determined by our meetings with Polish researchers of Conrad in the Centre for Conrad Studies at the Jagiellonian University, chaired by Prof. Jolanta Dudek, as well as by our membership in the Polish Society for Conrad Studies presided by Zdzisław Najder. Much rewarding is also our collaboration with Stefan Zabierowski, Agnieszka Adamowicz-Pośpiech, Magda Heydel, Prof. Wiesław Krajka, and with others. At a later stage of our work, Prof. Krajka, charged with the edition of an international academic series, invited us to publish our work in one of its issues titled Conrad: Eastern and Western Perspectives. The editorial team encouraged us to focus on Conrad's Bulgarian reception and brought us through to foreign scholars of Conrad such as John Peters, Anthony Fothergill, Stephen Donovan. The assistance of the Polish Institute in Sofia was also indispensable.

${ }^{13}$ Asparuh Asparuhov, Margreta Grigorova, "Under Bulgarian Eyes: The Reception of Joseph Conrad in Bulgaria," Yearbook of Conrad Studies (Poland) 8 (2013), pp. 47-63; M. Grigorova, P. Tsoneva, "Perspectives on the Contemporary Bulgarian Cultural Space: Conrad, Bulgarians and the Sea," Conrad: Eastern and Western Perspectives, vol. 27, Joseph Conrad's Authorial Self: Polish and Other, ed. W. Krajka (Lublin-New York: Maria Skłodowska-Curie University Press-Columbia University Press, 2018, pp. 335 369; Petya Tsoneva, "Notes on Margreta Grigorova's Monograph Joseph Conrad Korzeniowski: The Creator as Seafarer," Yearbook of Conrad Studies (Poland) 8 (2013), pp. 31-46; Kamen Rikev, "Joseph Conrad in Bulgarian Waters," Zeszyty Cyrylo-Metodiańskie 2 (2013), pp. 159-161.

${ }^{14}$ Margreta Grigorova, "Joseph Conrad Korzeniowski. The Creator as Seafarer (Excerpts)," Yearbook of Conrad Studies (Poland) 8 (2013), pp. 31-46 (trans. Petya Tsoneva); Margreta Grigorova, "Specular 
A special round anniversary edition of the leading paper for literature in Bulgariathe Literature Gazette - was published in 2017. ${ }^{15}$ The editorial, entitled "The Pole of the World," was followed by a set of translated critical reviews published in 2018 in the Literature $^{16}$ journal of Sofia State University. Normally, when the matter concerns a writer of such enormous stature, the anniversary year cannot contain all the events dedicated to him and is therefore extended beyond its calendar limits. Such is the case with the performance about which we write.

Our latest observations of the literary works produced in response to Conrad's life and fiction led us to the conclusion that his Bulgarian reception is intricately linked with the development of the Bulgarian maritime literature itself conditioned by the shifting political and economic significance of the sea. ${ }^{17}$ The beginning of this process can be traced back to Conrad's death and coincides with the publication of the first issue of Morski Sgovor magazine in 1924, which collected some works of Conrad's early translators as well as articles and writings inspired by his life and work (Dobrin Vasilev and Bistra Boshnakova's works, for instance). Conrad's influence has likewise conditioned the maritime fiction produced after the Second World War by writers like Varban Stamatov (born in 1857, the year of Conrad's death, he passed away in 1998), Boris Aprilov Ahoto (1921-1995), Nikola Radev (1940-2016), Todor Valchev Koruev, nicknamed the Sea Wolf (1935-2010), Georgi Ingilizov (1955-2018). Conrad's life and work informed long-distance sea captain Vasil Valchanov (1915-2017) and Vasil Dachev's (1932-) memoirs as well. Conrad's influence is discernible in the authors' concern with the sea and sailing, in their biographical experience and in the poetic specifics of their works. Typhoon, Conrad's first published book, turns out to be one of the most widely appropriated works whose multiplication is remarkable. Rusi Russev's initial translation in 1928 was later followed by Svetoslav Piperov's version published in the first volume of Collected Writings in Five Volumes, edited by Hristo Kanev and published by Georgi Bakalov Press. This text is crucial to Conrad's Bulgarian reception as it re-emerges in Varban Stamatov and Vasil Valchanov's works in fascinating relocations of certain situations, like the extreme weather and the human efforts needed to harness it, to restate

Transformations of Joseph Conrad's Philosophy of the Sea in Life of Pi (The Novel and the Film) - Reflections on the Transition between the Twentieth and Twenty-First Century," Yearbook of Conrad Studies (Poland) 10 (2015-2016), p. 2. Petya T. Ivanova, "The Sea as Moving Threshold. Spaces of Transition in Joseph Conrad," in National Literatures and the Process of Cultural Globalization, ed. Irma Ratiani, Shota Rustaveli (Tbilisi: Institute of Georgian Literature, 2014), pp. 137-146. Margreta Grigorova, "Waterways and Air Lanes: Spaces of Transition in Joseph Conrad, Antoine de Saint-Exupéry and Salman Rushdie," Yearbook of Conrad Studies (Poland) 10 (2015), pp. 95-102; as well as over ten thematically diverse articles on Conrad authored by M. Grigorova and published in Polish and Bulgarian editions.

${ }^{15}$ See M. Grigorova, "Joseph Conrad Korzeniowski-the Pole of the World."

${ }^{16}$ Literature magazine no. 18, published by the Faculty of Slavic Studies of Sofia University and edited by Prof. Ivan Nikolov, features John Peters, Robert Hampson and three Polish scholars of Conrad. Prof. Amelia Licheva, who took active part in the events and initiatives in honour of Conrad, was in charge of this thematic series.

${ }^{17}$ This is the thematic subject of our above-mentioned article "Perspectives on the Contemporary Bulgarian Cultural Space: Conrad, Bulgarians and the Sea." 
Conrad's conclusion that direct confrontation rather than circumvention is the right way to handle a storm. Our investigation and observations are open to readjustments, and we are particularly delighted that Conrad continues to inspire Bulgarian artistic circles. The artistic reception of Heart of Darkness occurred at a later stage of the researched period, supposedly triggered by the release of Francis Ford Coppola's Apocalypse Now in the 1980s (and its extended 2001 version), which shook Bulgarian viewers and caused new or, in some instances, first readings of this masterpiece of Conrad. The news about the Bulgarian stage adaptation of Conrad's work came as a pleasant surprise to us, verifying the importance of Coppola's film to Conrad's creative reception in Bulgaria.

Based on historical retrospection, but directed at the current context of reception of Conrad's work, our research registered a continuously evolving community of scholars and artists sharing a variety of commitments to the works of the seafaring writer. We used to hold and continue to stick to the point that the rise of communities $^{18}$ whose constituent members maintain a close scrutiny of the writer's works, is a natural indicator for the development of Conrad studies, as well as one of the world markers of his reception. This impulse has brought about a number of meetings, discussions and interviews which promoted the occurrence of some interest-rousing circumstances and conclusions. Following our firm belief in the eloquence of the interview as a form and means of gaining insight into certain authorial decisions, we decided to include fragments of our conversation with Valeria Valcheva, the Bulgarian stage director of Heart of Darkness, referenced with footnotes or quoted throughout the article. ${ }^{19}$

Some of the members of the play-inspired community and their comments on Conrad's stage adaptation are listed below for the purposes of the present article. ${ }^{20}$

Prof. Pravda Spasova, PhD, Professor of Philosophy at the National Academy of Arts, Sofia; senior research fellow, DSc at the Bulgarian Academy of Sciences:

Joseph Conrad is not among the authors best-known to the Bulgarian audience. Even Coppola's film Apocalypse Now was not widely recognised as being inspired by Conrad's most famous novel Heart of Darkness. That is why I watched curiously Valeria Valcheva's performance and I was very pleased with her directorial reading. Employing music and impressive visual artistic repertoire, the spectacle eventually put in front of the viewer the deep existential questions posed by J. Conrad, leaving no room for any minor interpretations inclined toward racism or criticism of imperialism, which are often presented as the only clue to this novel.

${ }^{18}$ The societies for Conrad studies are world-wide, including England, Poland, US, Japan and many other countries. See, for instance, Ośrodek Dokumentacji i Badania Twórczości Josepha Conrada—Kraków, http://www.conradianum.polonistyka.uj.edu.pl; Joseph Conrad Society (UK) —www.josephconradsociety. org; The Joseph Conrad Society of America — www.engl.unt.edu; Société Conradienne Française — www. flsh.unilim.fr/conrad; The Tokyo/Kyoto Conrad Group-wwwsoc.nii.ac.jp/conrad.

${ }^{19}$ The interview was held in the form of a conversation on 22 January 2019 and completed afterwards in the course of a written correspondence. Henceforward it will be referred to as "Interview."

${ }^{20}$ This feedback was assembled on 22 February 2019 after a month-long correspondence with Valeria Valcheva. 
Ivayla Radulova, film and TV scriptwriter and translator:

Travel with this crew to the "Heart of Darkness" and you will feel enlightened! The unique combination of classical literature, modern stage direction, skilful acting, ingenious stage and costume design, plus the original music (live playing, singing and dancing) turns this theatre into a sublime and provocative experience for the audience.

Yasen Vasilev, theatre stage director; writer:

The performance, set in the alternative space of a contemporary art museum, starts with an unexpected cabaret-like musical presentation with a band entirely formed by the actors in the piece. After it ends the audience is invited to follow the actors into another space as they now start to embody Conrad's characters and we all enter the world of the novel. The following long-lasting performance is a dramatization of the novel presented within a fascinating and constantly changing stage form of dream-like effects. The performance unrolls as slow and moody as Conrad's prose and allows a full immersion into the "heart of darkness."

Maria Kostova, English studies researcher:

I was really impressed by how the performance encompassed Conrad's fictional world. It seemed to me that I was going through its pages, it was an epic experience in the literal sense! Visually it was stunning: rough, and yet sophisticated, especially set and props, Kurtz for example. On the other hand, the cabaret start made me expect something more of that kind, and I really wanted it to last longer, or to be repeated throughout the performance. This would have meant, probably, less Conrad in all.

Valcheva herself is convinced of the affiliating power of Conrad's works. She was pleased to see how her dramatization of Heart of Darkness spurred the rise of a Conradian community even among the audience of the performance. Valcheva's perceptive approach to his sense of community turns out to be one of the reasons for her creative decision to introduce a "Secret Society Club" at the beginning of her screenplay. This is a definite signal that Conrad's reception is consistent with his own programmatic conviction that a community is an entity established by universal experiences and values. Stated in the original introduction to The Nigger of the "Narcissus" and quoted in the performance poster, the need for collective experience navigates the course of the performance till its end. ${ }^{21}$ It is likewise worth noting that this latter novel is one of Conrad's works which proves that the team (crew) wins recognition through trying experiences and care for the salvation of those who need it. The motif of salvation, though intertwined with a radically dissimilar, diabolic and multi-notional plot (not by chance approached as an instance of codified modernity) is also one of the thematic concerns of Heart of Darkness ("Save me, Save me!,"

${ }^{21}$ The idea of the "abiding mystery of the sublime spectacle" that people experience in a subconsciously similar way, underlies Conrad's very first (1897) programmatic introduction to The Nigger of the Narcissus (see Joseph Conrad, The Nigger of the "Narcissus": A Tale of the Sea [Garden City, NY: Doubleday, 1914], Harvard College Library [digitized by Google and uploaded to the Internet Archive], pp. 12-16). The Introduction lays out Conrad's concept of the communicative aspect of art (see Stanisław Modrzewski, Conrad a konwencje. Autorska świadomość systemów a warsztat literacki pisarza [Gdańsk: Uniwersytet Gdański, 1992], p. 14). 
is the outcry of Kurtz who, having lost his soul and been transformed into ivory, implores his confessor Marlow). Valcheva's play interprets that particular thematic aspect as well.

Valeria Valcheva's stage adaptation of Conrad was first set in 2017-2018, almost in synchrony with the adaptation staged by a British theatre company called imitating the dog, and often referred to as "a visually rich, multi-layered work which fuses live performance with digital technology," 22 alongside the Polish dramatization of Ciemności (The Darkness), produced by Monika Strzępka and based on Paweł Demirski's screenplay, where Marlow and Kurtz are represented as a pair of doubles - two Marlow figures (a woman and a man) and two Kurtz figures (a nineteencentury one and a contemporary one, respectively). ${ }^{23}$ The observed synchronicity of these productions directs further attention to their concentration within such shorttime period and the dialogue of interpretations this co-occurrence encouraged (evidently stimulated by the anniversary commemorated in 2017). The common ground of these three performances is the contemporary appeal of Conrad's work that seems to have been able to raise its questions and ideas in almost any historical period including the existential, cognitive and political context at the turn of the twenty-first century, the idea that Heart of Darkness keeps us alert on the problematic and absurd nature of humans and the human world. Imitating the dog's adaptation is accomplished as an experimental and modernist rendition, stylistically handled as a production that combines videographic techniques "an animated Cinemascope graphic novel is projected on the hanging screens" and acting. Both the Polish and the Bulgarian productions were inspired by Coppola's interpretation. Valcheva explains that she did consider the multiplication motif as a possible dramatic tool for rendering the interrelated characters of Marlow and Kurtz, but she was willing to figure out her own approach to this case. She further adds that Conrad's anniversary was the time for her creative reconnection to the author rather than the administrative framework for celebrating his memory.

The third edition of the only Bulgarian translation of Heart of Darkness came out in 2018. Translated by Grigor Pavlov, it provided the textual basis for the screenplay of the performance. The subsequent dramatization of the novel is a good reminder of several previous attempts to stage the text with a particular focus on the vocality of Conrad's work, captured in the brilliant voice of Orson Welles, who initiated its first dramatized interpretation for radio theatre broadcast. ${ }^{24}$ The dramatic potential of Conrad's works and their inherent stagecraft ${ }^{25}$ can therefore be seen as the implicit dimension of his heritage, particularly as regards his masterpiece Heart of Darkness. Apparently, this latent aspect of dramatic expression motivated Valcheva to persist in

${ }^{22}$ Play announcement of imitating the dog at http://www.imitatingthedog.co.uk/heart-of-darkness/.

${ }^{23}$ Play announcement at http://artmundus.pl/2018/01/16/premiera-ciemnosci-monika-strzepka-i-paweldemirski-w-teatrze-imka/.

${ }^{24}$ Orson Welles's radio dramatization was carried out in 1938 but the cinematic interpretation was thwarted by the Second World War.

${ }^{25}$ For a more detailed critical reading of One Day More, Victory, The Secret Agent, see Richard J. Hand, The Theatre of Joseph Conrad: Reconstructed Fictions (Houndmills, Basingstoke: Palgrave Macmillan, 2005). 
her decision to stage Conrad: "I sensed it and said to myself, that the text somewhat better fits the stage," she shared in a conversation with us.

Conrad's Heart of Darkness lends itself to staging for a couple of other reasons. Unlike his typical maritime works which project Conrad's favourite shoreless oceanic expanse as both benevolent and hostile, the serpentine line of the muddy river invites us on a kind of claustrophobic journey, which evokes associations with a dark tunnel through the heart of the monstrous jungle or a dark curtain behind which horror awaits to engulf those who take a look (as we will later see, that is one of the scenographic representations of the jungle in the performance). The journey goes through concentric circles till it reaches the bottom of hell or the end of the world; each circle being a location where Marlow encounters yet another mediator on his way to Kurtz until he comes to Kurtz's deathbed (this is yet another pattern artistically reproduced in the screenplay and activated by the performance). We are familiar with Conrad's weariness with the actual journey that engendered the story; we are likewise aware of his ambiguous experience of the "magic of revulsion" and his willingness to reveal what he had heard and seen so as to enable us to get insight into it (these motifs are also problematized by the play). The absurdity of the situation, which the author of Heart of Darkness must have felt involved in, escalates in the text which continues to be an everlasting artistic record of Conrad's insights that come to life intact in the discussed contemporary adaptation. His work is also remarkably suitable for the stage because of its clearly delineated farce figures, situations and dialogues. The intricate connection between internal and external space, between actual and symbolic world; between myth, ritual and reality; the quest itinerary; the dynamic interaction of monologue, dialogue and happening; the exceptional importance of vocal and verbal expression; the presence of a dramatic plot centred on the main character and demanding an actor capable of personifying and reflecting this extreme mode of existence: that all makes Conrad's masterpiece suitable for the stage and Valeria Valcheva's production has decoded these aspects by finding an appropriate representation for each of them.

What inspired the present discussion of her stage adaptation is a video recording of the performance, ${ }^{26}$ followed by talks and exchange of mails with the producer and close reading of the play script. Our observations focus on the artistic ideas, decisions and practical implementation of the producer's vision realised by stagecraft, music, scenery and props. All of these components are in fact constituent elements of one whole analytical and creative paraphrase of the work and its author.

We dare allow ourselves a translation of the announcement of the play since it contains some of the principal footings for both analysis and interpretation:

Heart of Darkness is an emblematic work in European modernism inspiring poets, composers, philosophers, film and theatre producers. Its text is a story narrated from first person singular by a sea captain Marlow in which he relates his bizarre experience on a boat travelling along a wide yellow river, deep into the continent of Africa, stopping at depots of ivory trade. At the end of this journey the protagonist finds and meets Kurtz - a dying European, who has become

${ }^{26}$ For further reference, see the full record at https://www.youtube.com/watch?v=XSsarVgOIqk. 
a deity for the natives whilst for us his character embodies a prophetic presentiment, which dates back to 1899 , of the rise of the great dictators of the twentieth century.

English writer Joseph Conrad whose background is that of a Polish aristocrat, was indeed a boat captain who had navigated the River Congo for nine years before Heart of Darkness appeared. Most of his characters have real prototypes and stories behind them. Kurtz is the only collective character in the book. Conrad himself formulates his goals in this way: "My task is, through the power of the written word, to make the readers hear, make them feel and, before all, make them see."

By adhering to the writer's credo, the producer Valeria Valcheva has created a miniature "Conradian community" consisting of a musician, a stage designer and five actors: seven persons in all on the stage, who will play as a modern company of actors relating the story of Heart of Darkness by way of farce, cabaret and ritual theatre in order to make the spectators "hear, feel and see."

The company seem enchanted by the spirit of mysterious adventure that encompasses everything in this book apart from or rather along with the profound thoughts.

Yet why Heart of Darkness here and now? Is it because of the colonial crises then or the migrant crises of today?

Joseph Conrad questions the existential foundations of human nature. We need to flesh them out in an appropriate way, even though Conrad was convinced that the human quest for answers has always been haunted by an anxious anticipation of the answers. That is what exactly happens with his enigmatic character Kurtz. "I think he realised it right at the end, but only then. The jungle had discovered it early on and had taken its revenge on him for the invasion he was part of. It whispered things to him, things about himself that he didn't know until he was out there alone. That whisper echoed loudly inside him because he was hollow."27

This preamble to the performance foregrounds a few of the most appealing properties of the play that motivate the direction of the stage work and the breadth of the goals the performance team intended to pursue. At the same time, a layer of Conrad's sententious thought that can be found in the initial foreword to The Nigger of the "Narcissus" (in the first published edition of 1897) and that has often been cited as the basis of his creative agenda, transpires in the production director's deep conviction of the necessity to see Conrad on stage: "My task which I am trying to achieve is, by the power of the written word, to make you hear, to make you feel- it is, before all, to make you see. That - and no more, and it is everything." 28

Indeed, any adaptation is a matter of responsibility. Justice, this very particular principle of Conrad's writing, now takes the shape of a responsible interpretation of the authorial text which enables the negotiation between ethical responsibility and creative approach. "Conrad makes your moral horizons expand," Valcheva adds, and

${ }^{27}$ Valeria Valcheva, "Sartzeto na mraka po novelata na Dzhouzef Konrad s rezhisyor Valeria Valcheva," 1.11.2017, https://nationalgallery.bg/bg/events/heart-of-darkness-based-on-joseph-conrads-novel-and-directed-by-valeria-valcheva/; Valeria Valcheva, "National Gallery Sofia Arsenal - Museum for Contemporary Art and Theater Viatar Association presents Heart of Darkness theatre performance, based on the novel by Joseph Conrad, director Valeria Valcheva," http://sofiaarsenal-mca.org/en/events/heart-darkness.

${ }^{28}$ Conrad, The Nigger of the "Narcissus," p. 14. 
her statement confirms the unanimous conviction of critics and scholars that Conrad's writing inspires responsibility.

\section{CONRAD TRANSLATED}

The translation of Heart of Darkness became available to the Bulgarian readers fairly late, accomplished by Grigor Pavlov in 1971 (when twelve of Conrad's works had already been published in Bulgarian, eight of which came out before the Second World War) and was published as a separate book with an introduction by the translator himself. The second edition which came out with minor corrections was included in the above-mentioned five-volume collection compiled by Hristo Kanev. Bulgaria's post-war communist past conditioned Conrad's reception in a controversial manner. While it did restrict the translation and circulation of some of his works, others enjoyed an eager welcome and were embraced as literary evidence to help expose imperialism and colonialism, and formulate the individual's social responsibilities. Furthermore, 1971 turned out to be one of Conrad's most prolific years in Bulgaria. Grigor Pavlov translated and edited Nostromo and Hristo Kanev completed his translations of Youth and The Shadow Line (two of Conrad's works most avidly translated into Bulgarian). As Asparuh Asparuhov and Margreta Grigorova point out, "Hristo Kanev has translated more of Conrad's works than anyone else in Bulgaria." ${ }^{\prime 29}$ Here included is also the translation of Lord Jim (1968). Pavlov's reputation as one of Conrad's most prolific translators is equally impressive. Asparuhov offers the following more detailed account of Pavlov's translation of Heart of Darkness: "Wishing, no doubt, to bring Conrad's text closer to the contemporary reader, the erudite translator Grigor Pavlov-lecturer in American literature at Sofia University-sometimes breaks up Conrad's longer sentences into shorter segments and compresses some of his phrases. ${ }^{30}$ It is this very segmentation and compression of Conrad's text that lends vigour to the theatrical adaptation. Generally, one of the technical requirements for theatrical adaptations is compression, and we will explore some of its other characteristics later in our work.

Pavlov was a prominent intellectual who actively participated in the Bulgarian cultural life, mediating between literature and theatre. Along with his academic career of a lecturer in English and American literature at Sofia University, he was one of the directors of the Department for translation of fiction of the Bulgarian Translators' Association, a translator for the UN mission in New York and a renowned translator of drama. His published translations include works by Edward Albee, an American theatre-of-the-absurd playwright who was conferred Doctor Honoris Causa degree by Krastyo Sarafov National Academy for Theatre and Film Arts in 2009. He translated Who's Afraid of Virginia Woolf? (1972, set on stage in 2006) and The Zoo Story (1959) (staged in two performances directed, respectively, by Kirkor Azaryan in

\footnotetext{
${ }^{29}$ Asparuhov, Grigorova, "Under Bulgarian Eyes,” p. 51.

${ }^{30}$ Asparuhov, Grigorova, "Under Bulgarian Eyes,” p. 52.
} 
1974, and Leon Daniel in 2005); Long Day's Journey Into Night (1941) by Eugene O'Neil (performed in 1956); Two for the Seesaw, William Gibson's Broadway debut, set many times in Bulgaria both on stage and as a radio theatre; The Ballad of the Sad Cafe (1951) by Carson McCullers, co-directed with Lyuba Madjarova (1984). Pavlov translated mostly drama - and his translation of Heart of Darkness certainly points to the dramatic potential of the text that Valcheva taps and develops in her performance.

Pavlov was apparently impressed by Conrad's work as he likewise wrote a critical article and a foreword to the first edition of his translation that though bearing the imprintment of communist ideology through its paradigmatic assertion of the clichéd case of bourgeois individualism, are nevertheless worth considering as they offer insight into the message and the poetic vigour of Conrad's word, whose poetic properties become most accurately accessible in the process of translation. The most substantial conclusions he makes refer to the fundamental relationship between the characters of Marlow and Kurtz: "In no time the author begins to arrange the scene of the volcanic confrontation between Marlow and Kurtz, and the denouement of the dramatic conflict follows suit," Pavlov writes, "Marlow is confounded by the possibility that he might have also fallen into the grip of Kurtz's magnetic attraction. This is an ominous and mysterious perception which determines his commitment to Kurtz's fate. Actually, both of them originate from the same cultural and historical context, don't they?"31 Pavlov's discerning comments on the paired identities of Marlow and Kurtz that concentrate the inward dynamics of the play, are particularly relevant to the stage production as the accumulated tension finds a new creative vent for its release in there.

The first publication of Heart of Darkness in Bulgarian in 1971 coincided with the rising popularity of some critical paradigms on his work available to the Bulgarian readers. Published the same year, Tzvetan Todorov's French edition of Poétique de la prose contributes an interpretation of Conrad's fiction authored by the prominent scholar of Bulgarian origin and preceded by his earlier book Introduction à la littérature fantastique, published in 1970. Poétique de la prose discusses the novel in a separate chapter entitled "Knowledge in the Void: Heart of Darkness," in which Todorov argues that its dominant plotline is more likely to unroll at the conceptual level of knowledge and interpretation than through direct action, and that to reach the "heart of darkness," one needs to journey to the incognisable void. ${ }^{32}$ This conceptual level of Conrad's work is likewise problematized in the play and is theatrically interpreted in a way that reveals how the quest for knowledge takes the shape of an extreme experience.

\footnotetext{
${ }^{31}$ Grigor Pavlov, "Introduction," in Joseph Conrad, Heart of Darkness, trans. Grigor Pavlov (Sofia: Narodna Mladej Publishers, 1971), p. 9.

${ }^{32}$ Tzvetan Todorov, "Poznanie na praznoto," in Poetika na prozata (Sofia: Nauka i izkustvo, 1985), pp. 178-191.
} 


\section{SOME NOTES ON THE SUBJECT OF THEATRICAL TRANSLATION}

In the Bulgarian case, Conrad's stage adaptation involves a number of textual and contextual relocations, where the Bulgarian translation of the novel turns out to be a major point of departure for the play. Grigor Pavlov's translation, which we mentioned earlier, underwent the usual readjustments characteristic of any theatrical adaptation where the original language and ideas are most often translated by the actors' own interpretations of the scenes (as, for instance, Yavor Kostov, who plays Marlow's part, rendered Conrad's text to stage language himself). However, the stage director specified explicitly that her stage translations are always text-focused. Some of the theatrical decisions nevertheless necessitated certain transformations of the text.

Such, for instance, is the description of the sepulchre-like city (most certainly hinting at Brussels), whose implied reference to the Gospel of Matthew (23:28) appears to concentrate one of the guiding ideas of the play: "Woe unto you, scribes and Pharisees, hypocrites! for ye are like unto whited sepulchres, which indeed appear beautiful outward, but are within full of dead men's bones, and of all uncleanness." ${ }^{33}$ Conrad's text reads: "In a very few hours I arrived in a city that always makes me think of a whited sepulchre. Prejudice no doubt." ${ }^{34}$ Pavlov's translation of whited actually fails to do justice to the Biblical subtext as the Bulgarian version of the Bible renders whited as whitewashed. For that reason the phrase a "whitewashed tomb" is substituted for "whited sepulchre" in the performance.

On another occasion the adaptation involves a more visible intervention in the original text. This can be illustrated by the following quote: "But what thrilled you was just the thought of their humanity-like yours - the thought of your remote kinship with this wild and passionate uproar. Ugly. Yes, it was ugly enough...," 35 where "Ugly, yes, ugly" is substituted for "Scary. Scary?" to fit the psychological mood of the play. It could be said, that the play intensifies Conrad's eloquent appeal and amplifies its vocality.

\section{CONRAD SET ON STAGE}

Obviously, Conrad's work has the power to select its translators and critics. The same goes for its stage directors. Heart of Darkness is staged almost 120 years after its first publication and 46 years after the publication of the Bulgarian translated edition, but the first prospects for its dramatization were discussed as early as the 1980s. Back then, it became necessary to read it through new, critically-just interpretive lens, to

\footnotetext{
${ }^{33}$ King James edition of the Holy Scripture.

${ }^{34}$ Joseph Conrad, Heart of Darkness, in Youth, and Two Other Stories (Garden City, NY: Doubleday, Page \& Co, 1925), p. 76.

${ }^{35}$ Conrad, Heart of Darkness, p. 123.
} 
redefine his position through a gesture of what we tend to see as a "discovery." Valcheva explains that her first school-time impression of Conrad involved a certain naïve assumption that he wrote adventure stories intended for children and adolescents - a view, partially conditioned by the formal design of the then published series that featured some of his works - such as the thematic series of More, bregove, hora (Sea, Coasts, People). Such clichéd categorization of maritime experience is, of course, barely compatible with Conrad's outlook and creative quests. Valcheva's husband ranks him among his favourite writers - their almost parallel professional trajectories (both of them majored in Bulgarian studies, though he took English as well, after which she specialised in the performing arts, while he did stage direction) and shared experience led to their later mature encounter with Conrad's work. Valcheva's enlightened vigorous inspection of Heart of Darkness informed her first plans for the future performance.

Conrad's "return" in the 1980s was nonetheless accelerated by Coppola's production Apocalypse Now, which can well be seen as the cultural event that lent new visual angles to the blinkered critical vision dominating Conrad's Bulgarian reception. Deeply impressed by Coppola's cinematic interpretation, with its soundtrack including works by Richard Wagner and The Doors (the effect of which left Tim Roth's more accurate and later cinematic adaptation far behind), and growing aware that the film was inspired by Heart of Darkness, the Bulgarian audience was seized by curiosity and desire to read or re-read the novel and know more about Conrad and his other works. This wave of revived interest spread most quickly among the students born in the 1960s. Valeria Valcheva belongs to that particular generation of young admirers of Conrad. She first read Heart of Darkness in the above-mentioned Collected Writings in Five Volumes edited by Hristo Kanev, and embarked on her research of the theatrical potential of the text in the 1990s when she started doing drama.

In the course of time, she reclaimed the spectacular appeal of Coppola's film not only in terms of its evocative power, but as a point of departure in her attempt to draw a discerning direction of comparison between the theatrical and cinematic approaches to Conrad's novel to help clarify in greater detail the specifics of the theatrical perspective. Two basic authorial conceptual decisions navigate her willingness to steer her own interpretation away from Apocalypse Now: Valcheva's firm conviction in the text's affinity to theatre and her willingness to foreground the Europeanness ${ }^{36}$ of its thematic concerns, most thickly concentrated in the "collective" character of Kurtz and in the overall direction of the European commitment to Africa.

\footnotetext{
${ }^{36}$ Zdzisław Najder provides one of the most comprehensive characteristics of Conrad's European ideas. He argues that they help address certain concerns. Conrad's European perspective is critical. Najder points out that he regarded European colonialism as a betrayal of its idealistic pursuits. Conrad's critical discussion goes even further. His political article "Autocracy and War" was initially titled "The Concord of Europe," which he revised to forecast the problematic grounds of European unity. In this article Conrad not only envisages the Russian revolution, but ruminates on the processes in the run up to the Second World War. See Z. Najder, Sztuka i wierność. Szkice o twórczości Josepha Conrada, trans. Halina Najder (Opole: Wydawnictwo Uniwersytetu Opolskiego, 2000), pp. 177-184; Z. Najder, Joseph Conrad: A Life, trans. Halina Najder (Rochester, NY: Camden House, 2007), p. 352.
} 
Valcheva acknowledges the impact of Apocalypse Now and is convinced that Coppola's production surpasses Tim Roth's cinematic interpretation, which does not do justice to the dramatic appeal of the play and reduces its effect by an excessive preoccupation with the thematic contents (a situation that raises the question of how close creative interpretations need to be to the original text). As we pointed out earlier, the dramatic potential of this particular work by Conrad consists of its capacity to resonate with the audience and to exert an inspiring influence through extreme experiences. However, Valcheva's critical appraisal of Coppola's version does not consider its monumentality in isolation from the obvious American implications of the war in Vietnam. She deciphers the universal message of Conrad's text, signalled, among other things, by the lack of toponyms - the nameless Congo river or the anonymous city (Brussels), which turns out to fit the theatrical conventions of conditional representation. Cinema, on the other hand, is more tightly bound to the specific whereabouts of geographical or historical locations - as is the case with Apocalypse Now or with Werner Herzog's Aguirre, the Wrath of God. The fact that Coppola's film represents a particular reading of the work's universal message actually assists its worldwide popularity due to the role of the US in today's globalisation and Valcheva considers this scenario as an ironic plot of the kind Conrad would have plotted himself.

The magnitude of Conrad's work, which she defines as "epic," motivates her claim that rather than being a novella or a fairly long story, Heart of Darkness can generically be identified as a novel. ${ }^{37}$

What professional credentials did Valcheva gain in her career prior to the moment she found herself in the position to carry out her long-term project? Having worked for seven years for state-funded theatres, Valcheva shifted to independent theatrical formations where her co-established "Teatar Vyatar" (Wind Theatre) Association belongs. She majored in Bulgarian studies and graduated from theatre studies with a major in stage direction in 1997. Valcheva has directed over thirty performances based on Bulgarian and world classic works by Shakespeare, Chekhov, Kafka and others, and her genuine interest in folklore underlies her experimental technique. As early as the beginning years of her artistic career she was willing to export theatre from the conventional space of its development and to transplant it into less typical but more inspiring settings, like art galleries, museums and parks that appear to liberate the spirit of the performance and to impart greater imagination to the process of the creative transfiguration of actuality, while, on the other hand, these locations in turn emanate the very metafictional space of the performance. This particular interaction between the performance and its setting is one of the defining characteristics of the productions she directs. Valcheva initiates and manages her recent Museum Theatre project in collaboration with the Museum for Contemporary Art in Sofia (MCAS). The first seven productions of Heart of Darkness take place inside the

\footnotetext{
${ }^{37}$ Generically, no critical agreement has been reached about the form of Conrad's work. Critical opinion varies between novella, novel, short novel or a (long) short story. Conrad himself referred to it as a novella in an exchange of letters with his publisher William Blackwood in December 1898 and February 1899.
} 
building of the museum and on the museum premises outside, and the next two performances are staged in the Red House of Culture and Debates "Panaret 7" in Sofia.

The invitation to one of the work gatherings held as part of the project agenda of Theatre and Space, reads:

After a couple of successfully staged productions, Valcheva began to build her own teams encouraging them to relocate the conventional setting of the theatrical performance to other places. This relocation gave birth to space-bound productions such as "200 000 Years" after Anton Chekhov, staged on the premises of the former Museum of the Revolutionary Movement; or "Deep High" after Arthur Rimbaud and Maurice Maeterlinck, staged at Paraklisa (Chapel) hall of the National Art Gallery; as well as productions that, initially conceived as text-based performances, have "migrated" to their self-chosen space - as, for instance, is the production of Hamlet performed in No. 40 Sculpture Studio of the National Art Gallery (co-directed by Mariy Rossen); and "Four Seasons' Dream," a rework of Shakespeare's classic, staged in Borisova Gradina Park and at Sofia Arsenal-Museum of Contemporary Art, a place whose architecture commemorates the beginning of the past century, with its refurbished ground floor, bare-walled first and second floors sheltered by a ceiling window and connected by a new glass staircase that descends to a large garden outside with an exhibition of sculptures. Apparently, the interior and exterior of the place provide a setting that stirs dramatic creativity. ${ }^{38}$

Just like space, time develops as a conceptual innovation in Valcheva's theatre. The calendar of her performances is not randomly fixed. In most of the cases, and synchronous with the sacred performing practices in the Bulgarian folklore, they coincide with major feasts in the vernacular ritual calendar that bind together Christian and pagan religious rites-for instance, she stages Shakespeare's A Midsummer Night's Dream on the summer solstice day, reworking the play's title through "A Midsummer Night's Dream on the Eve of Enyovden"39 to "Four Seasons' Dream," staging each performance in this series of variations on corresponding ritual dates of the solar calendar that happen to follow the chronology of St. John the Baptist's hagiography. Similarly, Twelfth Night is performed on 6 January (2019) when the church celebrates the Feast of Epiphany - the date Shakespeare himself chooses as a temporal reference in the play.

Valcheva combines various types of theatre in her productions depending on the performance itself and the intended effect. Thus, in terms of poetics, her creative quests are fairly diverse - apart from the expressive means of the ritual/sacred theatre, she employs realistic and psychological techniques, borrows from Bertolt Brecht, the puppet and musical theatre. Such various vehicles and tools of expression likewise constitute the technical means of her interpretation of Heart of Darkness.

This roughly sketched development of Valcheva's career enables her to gain sufficient insight and technique to set the play. She herself confesses that her projects need plenty of time to "mature"- she committed over twenty years to her Kafka Quartet performance and it took her even longer to stage Conrad. ${ }^{40}$ The pre-produc-

${ }^{38}$ For further reference, see Theatre and Space, http://sofiaarsenal-mca.org/bg/events/teatrt-i-prostranstvoto.

${ }^{39}$ Coinciding with the feast of St. John the Baptist's birthday.

${ }^{40}$ Dramatisation of Franz Kafka's miniature classics, staged by Valeria Valcheva in 2014-2015. 
tion period is the time needed for all elements, ideas, visualization, cast, production design and music to evolve till the moment when this concatenation will turn into symbiotic interaction. The stage director must see to it that each one of the elements is suitably chosen in a way that matches the others and in a manner that makes it an irreplaceable cog in the machinery of the performance.

For Heart of Darkness, this process begins with the decisive "appearance of Marlow." Valcheva's choice to give the role to Yavor Kostov, convinced in his outstanding performance in Samuel Beckett's plays, turns out to be absolutely right. Kostov's achievements likewise include the translations of two plays by BeckettStirrings Still, which Beckett completed shortly before his death, and Imagination Dead Imagine, where Kostov takes part in the many times of its performance directed by Yanko Velkov-Yanets. At first staged separately, the plays were later placed together in a joint composition. Like Marlow, the protagonist of Stirrings Still is the author's alter ego that undertakes an extreme self-quest journey beyond the limits of identity. As the play announcement makes clear, "adopting a third-person narrative perspective, he embarks on a final journey beyond the end of despair and reaches the very limit of the narration where retracting from himself he gives way to his premonition of a cosmic narration. [...] A zero-degree narrator guides his audience along this journey within an exceptionally limited space of unlimited opportunities experienced here and now." ${ }^{41}$ The announcement of the joint performance equally points out that "Imagination Dead Imagine represents an enigmatic visualization of the author's consciousness, a hermeneutic synthesis of verbal and visual representation, character and author, instantaneity and eternity, man and woman. Ascetic and multi-dimensional, unhomely and yet familiar, the text raises the unanswerable question of the human destiny. Stirrings Still comes instead of the answer to invite us to a journey beyond the story itself, which enables us to hear the inaudible and see the unseen in Beckett's last story." ${ }^{42}$

The subtle, intrinsic relationship between Heart of Darkness and Beckett's drama has apparently conditioned the director's choice of cast and her interpretation of Marlow's role. This comparative approach likewise contributes an expanding paradigm of reading Conrad's work in relation to another author, which is one of the merits of the discussed dramatic interpretation. Above all, the comparative lens enhances the dramatic potential of Conrad's novel as it refocuses our attention to it through the optics of Beckett's plays.

Valcheva's project was greatly assisted by production designer Martin Tabakov's skilful work. Martin Tabakov's work, which he presented at his sculpture graduation exam, impressed Valcheva and she invited him to make the Kurtz doll. He prepared the props and the masks, but, at the same time, he took an active part in the performance as an actor and singer, playing the double bass and his self-made percussion

\footnotetext{
${ }^{41}$ A schedule of the performances of Sfumato theatre workshop for 2014, http://theatre.art.bg/novina. php?news_id=3246\&city=20.

${ }^{42}$ Beckett $x 2$ play announcement published on the website of Plastelin Studio, http://www.atelieplastelin.com/2016/04/2.html. Imagination Dead Imagine was performed at the basement of the studio, and Stirrings Still—in the performance hall.
} 
instruments. Actually, singing is one of the innovative means of expression in the play where Marlow and some of his fellows set up the Heart of Darkness Band. Valcheva's cast consists of some of the most renowned freelance actors that come from such diverse professional areas as drama, puppet and dance theatre. The performance is likewise accompanied by live music improvised and produced on stage by percussionist Branko Valchev. Five of the seven members of the team have taken part in Valcheva's earlier stage productions. The entire team had to read Conrad's work meticulously and critically to be able to share in its collectively experienced reconstruction.

To meet this end, the team did an extensive research into Conrad's life and work, studied quite a few critical responses to his fiction, read through detailed information on the novel itself and its wider context, examined the discussions it spurred, dwelled on Africa and Congo, browsed through documentaries, films and pictures. The production design was based on pictures of the Chapman Lighthouse on the Thames, a landmark location at the beginning of the novel, and Marlow's steamboat, constructed for Orson Welles's suspended cinematic adaptation of Heart of Darkness. The latter represents a two-storeyed wooden construction, initially covered by rugs in muddy colours, which later turns into a tower, a river and a shack. When uncovered, it becomes Marlow's steamboat. The European borders are marked by a white-lace curtain while Conrad's "black" jungle is represented by a black curtain whose openings reveal parts of moving human bodies, masks, African basma, and the like.

The production team likewise studied the writer's fondness for his deceased cousin's wife Marguerite Poradowska. She reappears in Heart of Darkness as a roughly sketched silhouette, belonging to Conrad's critically represented realm of femininity (the stage director regards this particular paradigm as consistent with the commonly held patriarchal views in Europe at that time). Valcheva gives her a more prominent biographical part in her adaptation. There she is frequently addressed as "the cousin," not "aunt," and parts of Marlow's Congo narrative take the epistolary form of the letters she eagerly reads.

Besides such biographical details, Valcheva studies how Conrad interacts with other authors, some of whose texts she includes in the puzzle-like structure of the performance to enhance the suggestive intensity of its message. Such is the case with Edgar Allan Poe, ${ }^{43}$ Vachel Lindsay, Tom Waits, Thomas Eliot and even Alexander Pushkin's poems, which come to life in the songs of the performance. The play synchronises a variety of distinctive poetic utterances with the dramatized poetics of Conrad's work, its impact and composition. Fragments from Poe's "The Raven" and "Eldorado," Lindsay's "Congo," Waits's "I'll Be Gone" and "Temptation," and Eliot's "The Hollow Men," performed at the end of the play, contribute their particular tonalities to produce the polyphony of the play. The sense of mystery and nightmare activates the triple vocal harmony of Poe, Conrad and Lindsay, that modulates the initial effect of the cabaret repertoire (which also includes the children's play-

${ }^{43}$ Jeffrey Meyers sees Conrad as one of Poe's disciples as regards the horror and mystery effects, and his sceptical response to the ideas of progress and the moral underpinnings of the human world. See Jeffrey Meyers, Edgar Allan Poe: His Life and Legacy (New York: Cooper Square Press, 2000), pp. 292-293. 
song "Pop Goes the Weasel"). The Raven's dance is followed by poems about the late-coming night visitor, after which the cabaret, which also operates as a secret society, admits a grotesque Lady from the Society for Suppressing Barbarous Rites (the role is performed by a bearded man), who insists that she should be allowed to play her gig for the sake of charity. This session of performances concludes with a verse taken from American beat-generation poet Vachel Lindsay's poem "Congo." The air of fatality which Lindsay renders as part of Conrad's representation of Africa, and the pulsating rhythm of the rhymes and refrains, consciously chosen to paraphrase Conrad's work, match the rhythm and atmosphere of the performance and enhance their effect through the characteristic imagery of the river and the hell (whose fire engulfs Belgian king Leopold himself). ${ }^{44}$

Furthermore, the eponymous music band of Heart of Darkness was literally spurred by the performance. Music does contribute significantly to the communicative power of the play, which stems from the continuous interflow of the abovementioned poems adapted to songs and performed with a remarkable stylistic polyphony that brings together macabre, farce-like and almost mystical moments of revelation, along with "jungle motifs" composed of exotic speech and drum beat. "We are so happy that we came across the ethnographic record of 'Talking Drums' of Upper Congo," 45 the director explains in our correspondence, "which the band's percussionist studied and then trained the 'native African' actors how to articulate this Congolese rhythm." The contrastive transitions within the audio-verbal imagery generate additional effects. Such, for instance, is the caravan scene and the Eldorado song after Poe's eponymous poem; while the English children's song "Pop Goes the Weasel" is thematic and takes various forms including that of a farce-like march, or that of a chaotic "jungle voice."

The screenplay includes a total of twelve acts, the first three of which are introductory (they precede and anticipate the narrated journey). The opening scene introduces us to a certain Heart-of-Darkness Secret Cabaret Club where the songs after Poe and Lindsay's adapted poems help attune the audience's mood to meet Marlow and listen to the "unbelievably horrible story of Captain Charlie Marlow's adventures among the African Blacks (there are African Whites as well) along the Congo river at about the end of the nineteenth century, culminating in his encounter with the extraordinary, astounding, genius, tall Kurtz." ${ }^{36}$ Enter Marlow. His entrance is followed by

${ }^{44}$ In a letter published in Boston Evening Transcript (6 February 1915), he explains: "I hoped to imply Joseph Conrad's fatalistic atmosphere in his story 'Heart of Darkness.' I reached for the spiritual African fever he had in there that is the sure death to the soul. In my devices and setting for such phrases as 'Mambo Jumbo will hoo-doo you' I often had consciously in mind." See Peter L. Mallios, Our Conrad: Constituting American Modernity (Stanford: Stanford University Press, 2010), p. 187. Mallios further sums up the effect Heart of Darkness exerted on "The Congo": “ 'The Congo' thus offers an ideological 'vision' of Conrad - that is, it reflexively interprets Heart of Darkness in the attempt to re-create it - precisely as in each of the poem's three sections, the poem proffers a series of demonic, carnal, generally angry African-American bodies, only spiritually to 'reveal' them through a 'vision' of a fantastically attavised "Congo"' (Mallios, Our Conrad, p. 188).

${ }^{45}$ See Talking Drums of the Upper Congo, https://www.youtube.com/watch?v=7D10qcKOkKI.

${ }^{46}$ See the introduction to the play. 
the drinking scene at the cousin's house (when Marlow standing against the map of Africa tells about his childhood longing to explore its "heart"; and his cousin, convinced in the success of the "civilizing mission," realises that she can use her connections to help advance his career there). The scene is accompanied by Giuseppe Verdi's "Drinking Song" from La Traviata, whose parodic implications suggest the jubilant event needs its "ode of happiness." Act three, entitled "The Whitewashed Tomb," presents a demonic female ritual of spinning black yarn that wraps the entire space of the performance where Marlow is now the central figure. Standing beside him is a farcically represented doctor who sends him on the absurd mission.

The action then moves, along with the audience, to another place. Marlow's journey unrolls in nine acts which correspond to the nine circles of Dante's Inferno, in a comparative juxtaposition that does justice to the thematic logic of Conrad's work. The acts are entitled as follows: "Journey to the Heart of the Earth," "Jungle of Death," "Outer Station," "Caravan," "The Central Station," "Journey to the Beginning of the World," "A Voice," "Kurtz's Station" and "The Heart of Darkness Speaks," the last of which recreates Kurtz and Marlow's crucial conversation.

"This is a European story," Valcheva argues convincingly, as we proceed with our interview. The performance materialises this perspective. As early as the opening scene it introduces the symbolic topos of the early twentieth-century European cabaret, where Africans would traditionally be represented through so-called blackface, that is, by white actors whose faces were painted black (though black actors were available as well). Apart from being a culturally inscribed place, the European cabaret enters Valcheva's interpretation as a site of subversive re-enactment of colonial practices. Her choice to dramatize the play of masks not only activates the dramatic potential of Conrad's work, but it also demonstrates how he vigorously navigates the construction of multi-layered identities beyond culturally identifiable categories. The mask is an indispensable tool in Marlow's narration. It helps relativize the conceptual distance between imperial England and colonial Congo in many respects, including the verbal authority of its articulation. Thus, Marlow's story is literally "masked" by the darkness that settles down over the Thames, Kurtz's ethnic "whiteness" as well as the "white" idealism he embraces are persistently compromised by the pervading darkness of his practices, darkness itself is not synonymous with "blackness." Rather, it forms a transitional stage of visual perception that refers to ambivalence, ambiguity and lack of orientation. This transitional aspect of the novel destabilises certain imperial and colonial conceptual structures that we may be tempted to see in the racial connotations of his writing. Read through the lens of Frantz Fanon's Black Skin, White Masks model of self-location, where "whiteness" is the black subject's desire to play white, Conrad's narrative is suspicious of both the "white" and "black" façades of human being and, instead, employs them as masks that both reveal and conceal problematic identities. ${ }^{47}$ Masks in Valcheva's theatre serve other purposes, as well. In the cabaret, they not only enhance and simplify the theatrical representation of other, vernacular cultures, but also refer to the characters' lives and experiences.

${ }^{47}$ For further reference, see Frantz Fanon, Black Skin, White Masks, trans. Charles L. Markmann (London: Pluto Press, [1986] 2008). 
Even though the repertoire of the European cabaret contains adaptations of American poems, they do not divert the overall European focus of the production, but serve to prove its universal implications. "Our intention was to stage Heart of Darkness as a collective European story," Valcheva points out. "Kurtz is a collective European figure as well. Marlow is not the only narrator in the play. All characters join their voices to his. He remains alone on stage for only a couple of minutes."

Valcheva's perspective suggests an enticing new critical direction of reading Conrad's narrative as a collectively told story, where Marlow's account is preceded by an almost imperceptible all-pervading narrative space navigated by a collective narrator. Its most intensive section includes Marlow's encounter with Kurtz who operates as his demonic, shadow self in an ambivalently structured chronotope. Valcheva admits the intensity of the scene but she likewise observes that Marlow has many other shadow selves in the novel- the Russian sailor (one of the most discussed characters in the work), ${ }^{48}$ for instance. "I'm strongly convinced that the Russian is modelled after young Conrad," she notes in our correspondence, "When the Russian meets Marlow (Conrad's principal double, Kurtz being another one) Marlow actually encounters his adolescent self," Valcheva continues, but she also grounds her reasoning in this character's appealing personality, which Coppola borrowed to produce his cinematic counterpart, entrusting emblematic American actor Dennis Hopper with the performance of the role. "Actually, the character whose eulogy of Kurtz is Marlow's final signpost on his way to Kurtz's fortified dwelling, had to be Russian - Conrad needed the emblematic Russian type, well-known from classical Russian literature for being able to feel certain extreme, even religious awe at the wonder of being (significantly, the Russian trader's father is a priest), which he believes Kurtz embodies."

According to Valcheva, the narrative of Heart of Darkness points therapeutically to Conrad's recollected self. Having possibly released his traumatic memories of Russia that haunted him for a long time, he adopts a European perspective and regards Russia as a cultural participant in European politics from a critical angle that reminds of Virginia Woolf's insightful observations. ${ }^{49}$ Her work is mostly concerned with Russia's ambiguous liminal position of both an insider and outsider to Europe.

Apart from such political implications, the performance seeks to render every single element of the story as a collectively experienced moment, which, in turn, enables the experience of existential loneliness as a common human state. The question of existence finds its most intensive articulation as Conrad concludes that: "We live as we dream-alone." ${ }^{50}$ Understandably, this conclusion is placed in the mouth of the female Cousin who pronounces it as a sacred heartfelt thought.

${ }^{48}$ See James Morgan, "Harlequin in Hell: Marlow and the Russian Sailor in Conrad's Heart of Darkness," Conradiana 33, no. 1, pp. 40-49; Maciej Gloger, "Rosyjski arlekin. O nierozpoznanym motywie w Jądrze ciemności i o Rosji Josepha Conrada (prolegomena do kultury rosyjskiej)," Pamiętnik Literacki, no. 1 (2014), pp. 7-24.

${ }^{49}$ Ideas, well discernible in her writings on Russian literature (Dostoevsky, Chekhov, Turgenev, Tolstoy). See Roberta Rubenstein, Virginia Woolf and the Russian Point of View (New York: Palgrave Macmillan, 2009).

${ }^{50}$ Conrad, Heart of Darkness, p. 94. 
In the play, the two female characters introduced by Conrad as the dim fate-tellers standing at the gates of hell (the European trade company's entrance) are presented not only as actual individuals, but also as figures that point to archetypal symbolic and emotional states.

\section{THE JUNGLE, KURTZ AND MARLOW}

The topos of the jungle is represented as a multi-layered space-it takes shape as a vocal and symbolically-visual setting projected by means of music, stage design and choreography. Referred to as the "Jungle of Death" in the screenplay, it is technically set as a dark, two-tiered perforated curtain, whose openings serve to hold African masks expressing human suffering to illustrate Marlow's narrated encounter with the dying natives. In this context, one of the infernal circles in the play which Valcheva calls the "Circle of the Shriek," is also represented as an expressionist mask that symbolises the "horror." Most importantly, the jungle setting of the play is closely linked with Conrad's text from where its dramatic realization borrows the psychological dimension of its representation as a dark, unhomely, primordial and obsessive world, whose all-consuming vacuity gapes open, having engulfed Kurtz and his "torch of progress and civilization," and exposes the frittering façade of a lie that conceals bitter greed and thirst for power and possession.

The choreography of Kurtz's "love dance" with the overwhelming jungle is worth mentioning as well. The dance is performed by the actress who plays the part of Kurtz's fiancée, wearing the mask of a tusked elephant skull whose position she constantly changes. This brilliant choreographic decision lends a vibrant dramatic shape to the character of Kurtz's demonic lover whose outstanding appearance is described towards the end of the novel:

And from right to left along the lighted shore moved a wild and gorgeous apparition of a woman. [...] She walked with measured steps, draped in striped and fringed cloths, treading the earth proudly, with a slight jingle and flash of barbarous ornaments. [...] She must have had the value of several elephant tusks upon her. She was savage and superb, wild-eyed and magnificent; there was something ominous and stately in her deliberate progress. And in the hush that had fallen suddenly upon the whole sorrowful land, the immense wilderness, the colossal body of the fecund and mysterious life seemed to look at her, pensive, as though it had been looking at the image of its own tenebrous and passionate soul. ${ }^{51}$

At the same time, the dance operates as a transitional scene that introduces Marlow's encounter with Kurtz to whom the dancer bestows her final loving caress (the same actress plays the part of Kurtz's fiancée in a contrastive frame of reference).

"Kurtz is an exceptionally demanding character and finding a stage equivalent for him was a challenging task," Valcheva explains in her response to one of the most

\footnotetext{
${ }^{51}$ Conrad, Heart of Darkness, pp. 153-154.
} 
relevant questions asked about the dramatization of the text. Her perceptive opinion is that no human actor would be able to play his part adequately. Instead, she opts for a marionette, controlled almost imperceptibly and naturally as the plot unrolls, as though moved by the general mood of the narrative itself, or by the rest of the characters. Having emerged from his mostly vocal, spectral existence, as a largely described subject, Kurtz is only briefly allowed to breathe and act on his own. The design of Marlow's doll follows his physical description in Conrad's text-he is over six feet tall, lean, with a hollow chest. The marionette, designed as a string-doll, is, accordingly, put together as a long wooden skeleton with a huge, well-pronounced skull. Significantly, its traits remind of the actor who plays Marlow's part. The play stresses the paired identities of this theatrical couple in yet another way, as Kurtz the doll can only speak through Marlow's voice. In the decisive scene of their final conversation the actor who plays Marlow's part supports Kurtz the doll and speaks for him in a changed, wheezing voice. For the purposes of the dialogue (which actually happens as a split monologue) his utterances, pronounced in English, are left untranslated.

In conclusion, Valcheva's play is one of the most memorable creative reconstructions of Conrad's work in contemporary Bulgarian culture. It not only demonstrates the need for experimental space in the context of a rapidly growing cross-cultural awareness, but it also relocates certain aspects of Conrad's literary reception onto a wider plane of thinking. Thanks to an assembly of creative strategies and the performance of talented actors, singers, dancers and musicians, Heart of Darkness comes to life at the utmost of its vitality in a performance that lends maximum eloquence to every single detail of Conrad's work.

\section{WORKS CITED}

Asparuhov, Asparuh. Symbol and Scene in Joseph Conrad's Early and Late Works. Unpublished dissertation [1996].

Asparuhov, Asparuh, and Margreta Grigorova. "Under Bulgarian Eyes: The Reception of Joseph Conrad in Bulgaria." Yearbook of Conrad Studies (Poland) 8 (2013), pp. 47-63.

Conrad, Joseph. "Introduction." In The Nigger of the "Narcissus": A Tale of the Sea. Garden City, NY: Doubleday, 1914.

- Heart of Darkness. In Youth, and Two Other Stories. Garden City, NY: Doubleday, Page \& Co, 1925 (Book digitized by Google from the library of the University of Michigan).

Fanon, Frantz. Black Skin, White Masks, translated by Charles L. Markmann. London: Pluto Press, (1986) 2008.

Firchow, Peter E. Envisioning Africa: Racism and Imperialism in Conrad's Heart of Darkness. Lexington, KY: University Press of Kentucky, 2015.

Gloger, Maciej. "Rosyjski arlekin. O nierozpoznanym motywie w Jądrze ciemności i o Rosji Josepha Conrada (prolegomena do kultury rosyjskiej)," Pamiętnik Literacki, no. 1 (2014), pp. 7-24.

Grigorova, Margreta. “'Come and See for Yourself!'Valeria Valcheva, Director of the First Bulgarian Cinematic Adaptation of Heart of Darkness," Proglas 28, no. 1 (2019), pp. 137-142. 
. "Joseph Conrad Korzeniowski — the Pole of the World," Literature Gazette (2017/18), edited by M. Grigorova.

—. "Joseph Conrad Korzeniowski. The Creator as Seafarer (Excerpts)," translated by Petya Tsoneva, Yearbook of Conrad Studies (Poland) 8 (2013), pp. 31-46.

- "Specular Transformations of Joseph Conrad's Philosophy of the Sea in Life of Pi (The Novel and the Film) - Reflections on the Transition between the Twentieth and Twenty-First Century," Yearbook of Conrad Studies (Poland) 10 (2015-2016)

- Joseph Conrad: the Creator as Seafarer. Veliko Tarnovo: St. Cyril and St. Methodius University Press, 2011.

Grigorova, Margreta, and Petya Tsoneva. "Perspectives on the Contemporary Bulgarian Cultural Space: Conrad, Bulgarians and the Sea," Conrad: Eastern and Western Perspectives, vol. 27: Joseph Conrad's Autorial Self: Polish and Other, edited by W. Krajka, pp. 335-360. LublinNew York: Maria Skłodowska-Curie University Press-Columbia University Press, 2018.

—. "'Sartseto na mraka'-idei i resheniya na parvata balgarska postanovka" [Heart of Darkness on the Bulgarian Stage: Creative Perspectives and Techniques], Proglas 28, no. 1 (2019), pp. 35-46.

Hand, Richard J. The Theatre of Joseph Conrad: Reconstructed Fictions. Houndmills, Basingstoke: Palgrave Macmillan, 2005.

Karl, Frederick R. A Reader's Guide to Joseph Conrad. Syracuse: Syracuse University Press, 1960.

Mallios, Peter L. Our Conrad. Constituting American Modernity. Stanford: Stanford University Press, 2010.

Meyers, Jeffrey. Edgar Allan Poe: His Life and Legacy. New York, NY: Cooper Square Press, 2000.

Modrzewski, Stanisław. Conrad a konwencje. Autorska świadomość systemów a warsztat literacki pisarza. Gdańsk: Uniwersytet Gdański, 1992.

Morgan, James. "Harlequin in Hell: Marlow and the Russian Sailor in Conrad's Heart of Darkness," Conradiana 33, no. 1, pp. 40-49.

Najder, Zdzisław. Joseph Conrad: A Life, translated by Halina Najder. Rochester, NY: Camden House, 2007.

—. Sztuka i wierność. Szkice o twórczości Josepha Conrada, translated by Halina Najder. Opole: Wydawnictwo Uniwersytetu Opolskiego, 2000.

Nikolova, Kamelia. Balgarskiyat teatar sled 1989 i novata britanska drama [Post-1989 Bulgarian Theatre and New British Drama]. Sofia: Sofia University Press, 2013.

Pavlov, Grigor. "Vavedenie.” In Dzhouzef Konrad, Sartseto na mraka, translated by Grigor Pavlov. Sofia: Narodna Mladej Publishers, 1971.

Rikev, Kamen. "Joseph Conrad in Bulgarian Waters," Zeszyty Cyrylo-Metodiańskie 2 (2013), pp. 159-161.

Roussenova, Stefana. Dialogues in Exile: Joseph Conrad, Vladimir Nabokov, Eva Hoffman. Sofia: Polis, 2010.

Rubenstein, Roberta. Virginia Woolf and the Russian Point of View. New York, NY: Palgrave Macmillan, 2009.

Todorov, Tzvetan. "Poznanie na praznoto.” In Poetika na prozata, pp. 178-191. Sofia: Nauka i izkustvo, 1985.

Tsoneva, Petya. "Notes on Margreta Grigorova's Monograph Joseph Conrad Korzeniowski: The Creator as Seafarer," Yearbook of Conrad Studies (Poland) 8 (2013), pp. 31-46.

- "The Sea as Moving Threshold. Spaces of Transition in Joseph Conrad," National Literatures and the Process of Cultural Globalization, vol. 2, edited by Irma Ratiani, pp. 137146. Tbilisi: Shota Rustaveli Institute of Georgian Literature, 2014. . "Waterways and Air Lanes: Spaces of Transition in Joseph Conrad, Antoine de SaintExupéry and Salman Rushdie," Yearbook of Conrad Studies (Poland) 10 (2015), pp. 95-102. 
Valcheva, Valeria. "Sartzeto na mraka po novelata na Dzhouzef Konrad s rezhisyor Valeria Valcheva," 01.11.2017, https://nationalgallery.bg/bg/events/heart-of-darkness-based-on-joseph-conrads-novel-and-directed-by-valeria-valcheva/; English version: "National Gallery Sofia Arsenal - Museum for Contemporarz Art and Theater Viatar Assotiation present Heart of Darkness theatre performance, based on the novel by Joseph Conrad, director Valeria Valcheva," http://sofiaarsenal-mca.org/en/events/heart-darkness. 
